\title{
ZOOPLANKTON COPMOSITION OF SOME INDUSTRUAL POLLUTED AREAS IN THE RIVER NILE ECOSYSTEM
}

\author{
Adel A. Mageed
}

National Institute of Oceanography and Fisheries, 101 Kasr Al Ainy St., Cairo, Egypt

Key words: Zooplankton, River Nile, El Nubaria Canal, seasonal succession, pollution.

\section{ABSTRACT}

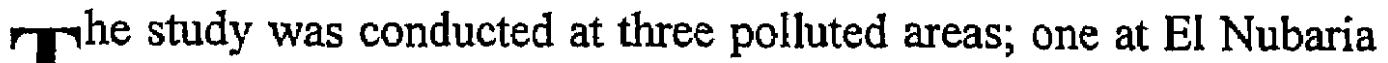
1 Canal in Alexandria, and two in the River Nile at El Tebbin and Helwan. The industrial residues of petrochemicals, iron and steel, as well as starch and glucose pollute these areas respectively. During the study, the samples were collected six times at El Nubaria Canal and seven times at El Tebbin and Helwan. The data were codified to express the seasonal changes. Three stations represented the area of El Nubaria Canal and four in River Nile; two at El Tebbin and two at Helwan.

The results of the total zooplankton abundance showed high density in the areas before pollution than at the mixing points. This observation was pronounced at petrochemical residues more obviously than that of steel and iron as well as starch and glucose factories.

The major taxa were represented by 14 species of Rotifera, 5 Cladocera, and 4 Copepoda at El Nubaria Canal, whereas in River Nile at El Tebine and Helwan, they were represented by 37 Rotifera, 8 Cladocera, and 3 Copepoda.

The diversity of Rotifera was the highest in the River Nile. Keratella cochlearis and Brachionus calyciflorus dominated the rotifers community. Cladocera was dominated by Bosmina longirostris, whereas Copepoda was dominated by Nitocra lacustris at El Nubaria Canal and by Thermocyclops hyalinus at the River Nile.

The maximum density of zooplankton organisms was recorded at the area before the pollution especially at El Nubaria Canal. Winter and autumn were the best seasons for zooplankton flourishing in $\mathrm{El}$ Nubaria Canal, whereas in the River Nile, winter and summer displayed the peaks of the zooplankton density. 


\section{INTRODUCTION}

Environmental pollution inputs are considered the most serious problems that face the River Nile and its tributaries. As industry increased in Egypt since the early 19th century, the River Nile received a lot of untreated wastes and residues from many plants. Alexandria and South of Cairo (mainly at Hawamdiya, El Tebbin, and Helwan) are the main industrial areas, which have about 38 and 1243 plants respectively ( $\mathrm{El}$ Gohary, 1993). According to the Helwan Master Plan (1978), the industrial wastewater discharged from the Helwan area (without El Badrasheen area) amounts to about $42,314,000$ cubic meters per annum (Bakry, 1996). Two main factories discharge their residues directly into the River Nile in this area without any treatment (The Egyptian Starch and Glucose Company as well as The Egyptian Iron and Steel Company).

At Alexandria, the Egyptian Petrochemicals Company (EPC) produces chlorine gas, sodium hypochlorite, liquid chlorine, ethylene, the monomer VCM, and the final principal product (polymer polyvinyl chloride - PVC). The company receives its water supply from EI Nubaria Canal, and discharges about 250,000 cubic meters per day of its residues into the same water canal. The drainage water becomes loaded with the residues of the plants that eventually contaminate the aquatic environment, thus exerting a hazardous effect on the living organisms.

Zooplankton community is a good indicator of any change in water quality, because it is strongly affected by environmental condition and responds quickly to these changes (Gannon and Stemberger, 1978). They have a distinct preference for some pollutants and some species can tolerate specific pollutants but at limited levels. Besides, riverine plankton communities are likely to exhibit changes depending on physical, chemical, and biological variables (Hynes, 1970; Reynolde et al., 1994).

The objective of this study was to examine the impact of some industrial residues on zooplankton organisms, in addition to the seasonal variations of these organisms. 


\section{MATERIAL AND METHODS}

\section{A. El Nubaria canal (Alexandria):}

The work at El Nubaria Canal was performed according to the protocol of cooperation between the National Institute of Oceanography and Fisheries and the Egyptian Petrochemicals Company-Alexandria for evaluation of water sources of the new uptake of the company at El Nubaria canal.

Three stations representing the canal (Fig. 1) were selected:

Station 1: At the suction pumps of the factories in El Nubaria Canal.

Station 2: After the mixing point by about one km.in the canal.

Station 3: At the point of mixing of the petrochemical residues with the canal water (after about one $\mathrm{km}$ of the first one).

The samples were collected during the period from January to October 1996 at approximately seasonal intervals.

\section{B. The River Nile (EI Tebbin and Helwan):}

The samples were collected from the River Nile at four stations: two at The Egyptian Iron and Steel Company (EISC) and two at The Egyptian Starch and Glucose Company (ESGC) (Fig. 2) as following:

EISC: Station 1: In the River Nile before EISC discharge.

Station 2: In the River Nile at the mixing point of EISC discharge.

ESGC: Station 1: In the River Nile before ESGC discharge.

Station 2: In the River Nile at the mixing point of ESGC discharge.

The samples were collected at seven times: January 1996 as well as April, May, July, August, October, and November 1997.

The samples of the study at El Nubaria Canal and the River Nile at El Tebbin and Helwan were collected by filtration of 100 liters of water through plankton net with 55 microns mesh size. The samples were fixed in $4 \%$ neutral formalin. Triplicate of $3 \mathrm{ml}$ subsamples of each sample were counted and identified in the laboratory according to Edmondson (1966); Rey and Saint-Jean (1968); Ruttner-Kolisko (1974); Pennak (1978); Pontin (1978); Edmondson and Lill (1987); Fernando et al. (1987); and Jeje (1988). 
$\mathrm{pH}$ and water temperature $\left({ }^{\circ} \mathrm{c}\right)$ were measured by Digital Orion pH meter (Model 211). Transparency was measured by black-white

enameled Secchi disc of $30 \mathrm{~cm}$ diameter. Turbidity, total solids and total dissolved solids of El Nubaria Canal were measured by the teamwork of NIOF during the study.

In order to provide a quantitative evaluation of the similarities or dissimilarities of the biota, the index of species similarity (ISS) was calculated according to the formula:

$$
I S S=\frac{C \times 100}{\mathrm{~A}+\mathrm{B}-\mathrm{C}}
$$

Where " $\mathrm{A}$ " and " $\mathrm{B}$ " are the numbers of species in community $\mathrm{A}$ and $\mathrm{B}$, while $\mathrm{C}$ is the number of species common to both (Lance \& Williams, 1967, Caspers \& Heckman, 1982).

ANOVA was done by Microsoft Excel Program 5.0/7.0 (1997). Values for ANOVA were considered significant at $\mathrm{P}<0.05$, as indicated by Rolf \& Sokal (1969).

\section{RESULTS}

\section{A-EI Nubaria Canal:}

$\mathrm{pH}$ at station 3 was higher than at stations 1 and $2(9.89,7.56$, and 8.20 respectively). The highest water temperature was recorded at station 3. Total solids and total dissolved solids at station 3 were more than about eight folds than at stations 1 and 2 . Transparency decreased from $120 \mathrm{~cm}$ at station 1 to only $60 \mathrm{~cm}$ at station 3 (Table 1).

A total of 19 species of zooplankton were recorded at the heavily polluted zone (mixing point-station 3) at The Egyptian Petrochemical Company (EPC) with an average of about 7616 organisms $/ \mathrm{m}^{3}$. These were 13 Rotifera, 5 Cladocera, and one Copepoda. The most abundant species in terms of numbers was Keratella cochlearis, which accounted about $28.89 \%$ of the total zooplankton number. It was followed by Brachionus calyciflorus. $(6.24 \%)$. The juvenile stages of Copepoda represented $15.30 \%$ of the total zooplankton counts (Tables $2 \& 3$ and Figs. $3 \& 4$ ).

There were 19 and 16 species recorded from the areas before and after the mixing (16944 and 7094 organisms $/ \mathrm{m}^{3}$ respectively), of these 11 and 9 were Rotifera, 4 as well as 5 were Cladocera, and 4 and 2 were Copepoda respectively. At station $1, K$ cochlearis was the most dominant species, followed by $B$. calyciflorus $(9.77$ and $8.85 \%$ 
Nile ecosystem

respectively. At station 2, Onychocampius mohammed followed by $B$. calyciflorus and $K$. cochlearis were the most dominant species (14.10, 10.57 , and $9.99 \%$ respectively). Generally, the total zooplankton

species that recorded at EPC in El Nubaria Canal were 27 species; 18 Rotifera, 5 Cladocera, and 4 Copepoda.

By applying similarity test, the value between station 1 and 2 was the highest $(59.09 \%)$ whereas that between stations 3 and 1 , and 3 and 2 were $46.15 \%$ and $52.17 \%$ respectively.

\section{Seasonal variations:}

Rotifera was the dominant group, constituting $43.21 \%$ of the total zooplankton. Rotifera dominated during winter especially at station 1 and station 3. During this period, Keratella cochlearis was the most dominant species (6375 organisms $/ \mathrm{m}^{3}$ ); the lowest density was recorded during spring. Brachionus calyciflorus was the second dominant rotifer during winter with maximum density at station 1 $\left(6000\right.$ organisms $\left./ \mathrm{m}^{3}\right)$ (Table 2 and Fig. 5).

Copepoda constituted $34.19 \%$ of total zooplankton. It was dominated during autumn especially at station 1 , followed by summer at the same station. Copepoda was dominated by Nitocra lacustris that recorded only during winter and spring with maximum density at station 1 during spring. Onychocamptus mohammed occupied the second order and it was recorded only during the other two seasons. The other species appeared as scattered forms in the different seasons. Nauplius larvae and copepodite stages represented $36.64 \%$ and $36.86 \%$ respectively, of total Copepoda (Fig. 6).

Cladocera occupied the third order; and constituted about $11.64 \%$ of total zooplankton. Cladocera was dominant during autumn especially at station 1 (4125 organisms $\left./ \mathrm{m}^{3}\right)$, but obscured totally during spring. Macrothrix laticornis was the most dominant cladoceran species, representing $18.38 \%$ of total Cladocera. $M$. laticornis was recorded only during summer and autumn with maximum counts at station 1 during autumn (2875 organisms $/ \mathrm{m}^{3}$ ) (Fig. 7).

Other taxa constituted totally $10.84 \%$ of total zooplankton. They are Nematoda $(73.05 \%)$, insect larvae (18.31\%), polychaete larvae (3.7\%), Tardigrada (3.7\%), and Ostracoda (1.24\%). 
River Nile (El Tebbin and Helwan):

I.EISC:

The $\mathrm{pH}$ values and water temperature were more or less similar at stations 1 and 2, but transparency decreased from $90 \mathrm{~cm}$ at station 1 to $30 \mathrm{~cm}$ at station 2 .

A total of 38 zooplankters were recorded at the mixing point with average of 108465 organisms $/ \mathrm{m}^{3}$. These were 31 Rotifera, 5 Cladocera, and 2 Copepoda. 39 species were recorded before mixing point, that counted 133412 organisms $/ \mathrm{m}^{3}$, of these 29 species were Rotifera, 6 Cladocera, and 3 Copepoda. A total of 43 species were recorded at the area of EISC; 34 Rotifera, 6 Cladocera, and 3 Copepoda. K.cochlearis was the dominant species at EISC area, that followed by $B$. calyciflorus (Tables $2 \& 3$ and Figs. $9 \& 10$ ). The similarity test value between the two stations was $75 \%$.

Seasonal variations:

The seasonal cycle of zooplankton at EISC showed one development peak in stations 1 and 2. It was composed of summer community (181868 and 176300 organisms $/ \mathrm{m}^{3}$ respectively) that dominated mainly by $K$ cochlearis (69.80 and $69.03 \%$ of total zooplankton number respectively).

Rotifera occupied the first order; and constituted $95.67 \%$ of total zooplankton density. It flourished during summer followed by winter at station 1 (179334 and 170400 organisms $\left./ \mathrm{m}^{3}\right)$, whereas at station 2, it increased in summer and spring (171300 and 109350 organisms $/ \mathrm{m}^{3}$ respectively). The rotifers were represented by 34 species, but only two genera;Keratella and Brachionus were responsible for their high densities. $K$. cochlearis represented $43.37 \%$ of total rotifers, and was dominant during summer. It was followed by B.calyciflorus that represented $34.83 \%$ of total rotifer organisms (Fig. 11).

Cladocera occupied the second order, and was represented by only $2.40 \%$ of total zooplankton density. Bosmina longirostris was the most dominant species ( $69.80 \%$ of total cladocerans). Its peak of flourishing was in winter at the two stations. Station 1 harbored higher density than the second one (Fig. 12).

Copepoda constituted $1.47 \%$ of total zooplankton, including Thermocyclops hyalinus, Mesocyclops leuckarti, and Nitocra lacustris. Juvenile stages represented $78.85 \%$ of total copepod density. The highest density of Copepoda was recorded during spring at station 1 and during summer at station 2 (Fig. 13). 
Other taxa of zooplankton constituted only $0.46 \%$ of total zooplankton density. Nematoda (65.06\%), insect larvae (28.95\%), and veliger larvae $(6.08 \%)$ represented them. The highest number was observed at station 2 especially during autumn. They disappeared from station 1 during winter (Fig. 14).

\section{II.ESGC:}

The $\mathrm{pH}$ values and water temperature were more or less similar at stations 1 and 2, but transparency decreased from $120 \mathrm{~cm}$ at station 1 to $50 \mathrm{~cm}$ at station 2 (Table 1 ).

Zooplankton community was represented by 43 species at ESGC area; 36 species were recorded at the mixing point, and 35 species were at station $1 . K$. cochlearis was the most dominant species, constituting $38.64 \%$ and $37.53 \%$ of total zooplankton at stations 1 and 2 respectively. Station 1 was richer than the second one (111888 and 92981 organisms $/ \mathrm{m}^{3}$ respectively) (Figs. 15 and 16). By applying similarity test, the value between the two. stations was $73.17 \%$.

\section{Seasonal variations:}

Rotifera constituted $93.96 \%$ of total zooplankton. K.cochlearis and $B$. calyciflorus were the most dominant rotifer species, and represented 40.59 and $33.02 \%$ of total rotifer counts respectively. The peak of rotifers was in summer at station 1 due to flourishing of $K$. cochlearis; whereas at station 2 it was in winter due to flourishing of B. calyciflorus (Fig. 17).

Cladocera was the second dominant group constituting $3.70 \%$ of total zooplankton number. It was represented by six species; Bosmina longirostris was the most dominant species $(76.89 \%$ of total Cladocera). It was followed by Ceriodaphnia cornuta $(20.00 \%)$. The highest numbers of Cladocera were recorded during winter due to the flourishing of $B$. longirostris (Fig. 18).

Copepoda constituted $1.76 \%$ of total zooplankton, including Thermocyclos hyalinus, Mesocyclops leuckarti and Nitocra lacustris. The first one was the most dominant species at the second station especially during winter. Juvenile stages constituted $76.11 \%$ of total Copepoda; they flourished during winter and spring with maximum counts during winter at station 1 (Fig. 19). 
Other taxa represented only $0.59 \%$ of total zooplankton, as they have been recorded mostly at station 2 with the highest density of Nematoda during summer (Fig. 20).

\section{DISCUSSION}

The total number of zooplankton organisms at station 1 of $\mathrm{EI}$ Nubaria Canal was more than double times of station 3 (16944 and 7616 organisms $/ \mathrm{m}^{3}$ respectively). This result is more pronounced by applying similarity test, which shows that the lowest value was between stations 1 and 3. Also by applying ANOVA (Table 4) the difference between the two stations was significant statistically; whereas the difference between stations 1 and 2 was not significant. This may be due to the effect of the total solids and the total dissolved solids at station 3. Hynes (1970) showed that these solids intermingle the digestive systems of the filter feeders organisms. Laal and Karthikeyan (1993) reported that rotifers were influenced mostly by chlorine as one of the residues of the Egyptian Petrochemicals Company. The bioaccumulation of the organic and inorganic micropollutants in the residues can exert harmful effect on zooplankton.

In the River Nile at El Tebbin and Helwan, the lowest transparency was recorded in the polluted areas $(30$ and $50 \mathrm{~cm}$ respectively). All nutrients and $\mathrm{Fe}$ levels at $\mathrm{El}$ Tebin were in the maximum values at discharging areas compared to the other sampling stations(Sobhy 1999). He found that $\mathrm{Fe}$ level at the discharging area were about 25 folds compared to the others. This result coincided with the lowest number of zooplankton at the polluted areas (108465 and 92981 organisms $/ \mathrm{m}^{3}$ respectively). By applying similarity test between the polluted and the non-polluted areas, the values were $75 \%$ and $73.17 \%$ for $\mathrm{El}$ Tebbin and Helwan respectively. ANOVA test indicated non-significant difference between the polluted and nonpolluted areas (Table 4). This was coincided with the results of Ramadan et al (1998) in the River Nile from Esna to Delta Barrage, where they found the highest standing crop of zooplankton at Helwan. Sobhy (1999) found that, the industrial waste of Iron and Steel Factories at the River Nile does'nt affect phytoplankton diversity. If such impacts do not occur, more insidious and not easily identifiable alterations may be caused by changes in feeding, growth, and other metabolic functions of given species (Menzel and Case, 1977). 
Alternately, populations may adapt metabolically so that no obvious effects are detected.

The maximum peak of dominance of zooplankton in El Nubaria Canal was during winter followed by autumn. In the River Nile; at El Tebbin and Helwan, it was during winter followed by summer, due to the dominance of Copepoda during this season. On the whole, zooplankton is primarily dependent on its food resource (i.e. the more phytoplankton, the more zooplankton). Sobhy (1999) observed that the maximum number of phytoplankton was at E1- Tebbin during winter.

Environmental factors play an important role in the abundance and species composition of zooplankton.

During this study, Rotifera represented $95.67 \%$ and $93.96 \%$ of the total zooplankton number in the River Nile at EISC and ESGC respectively. In El Nubaria Canal at EPC, it represented $43.21 \%$ of the total zooplankton number. Anon (1979) showed that Rotifera was the most dominant group in the River Nile (74.4\%). Ramadan et al. (1998) observed that rotifers represented $92.41 \%$ at Helwan region in the River Nile. In large rivers, true plankters often predominate and fast growing rotifers are often dominant (Hynes, 1970). Gannon (1981) indicated that Rotifera is a more sensitive indicator of water quality than crustaceans because rotifers can more rapidly respond to environmental changes caused by higher turnover rates.

Brachionus calyciflorus and Keratella cochlearis were the dominant zooplankton species in El Nubaria Canal and mostly in the River Nile at El-Tebbin and Helwan. Telesh (1996) showed that these species were numerous among Volkhov Bay, indicating polluted waters in the mouth of the Volkhov River (Russia). According to Sladecek (1983), these species were classified as alpha or beta mesosaprobic. Also, Saksena (1987) classified rotifers as bioindicators of water quality and he revealed that Brachionus calyciflorus and Keratella spp are inhabitants of moderately clean (mesotrophy) water. These species have the ability to resist some degrees of eutrophication and some kinds of pollution. 
Primary treatment is recommended for the industrial wastewater disposal to El Nubaria Canal and at E1-Tebbin and Helwan regions to conserve the River Nile ecosystem.

\section{REFERENCES}

Anon (1979). Some studies on the River Nile Ecosystem. Inst. Oceanogr. Fish. Inland Waters and Fish Culture Division. Academy of Scientific Research and Technology, Egypt, 81 pp.

Bakry, M. F. (1996). Aquatic weed infestation as a parameter of pollution along the Damietta and Rosetta Branches, Water Science, The $19^{\text {th }}$ issue, 18-24.

Caspers, H. and Heckman,C. W. (1982). Ecology of Orchard drainage ditches along the freshwater section of the Elbe Estuary. Arch. Hydrobiol., 43 (4): $347-486$.

Edmondson, W. T. (1966). Rotifera: In" Freshwater Biology" ( $2^{\text {nd }}$ ed), Edmondson (Ed.), New York, London, Jhon Wiely \& Sons, Inc, 14pp.

Edmondson, W. T. and Lill, A. H. (1987). Conochilus in Lake Washington, Hydrobiol. 147: 157-162.

El Gohary, F. A. (1993). Industrial wastewater management in Egypt. Second Egyptian Seminar on Industrial Wastewater Management, Cairo, Egypt, pp. 1-21.

Fernando, C. H.: Paggi, J. C.and R. Rajapaksa. (1987). Daphnia in tropical lowlands, Mem. Ist. Ital. Hydrobiol., 45: 107-141.

Gannon, J. F. (1981). Zooplankton of the Northern American Great Lakes, Assoc. Int. Limnol. Theor. Appl., 21 (3). 1725-1733. 
Zooplankton of some industrial polluted areas in the River 11 Nile ecosystem

Gannon,J.E.and Stemberger,R.S. (1978). Zooplankton especially crustaceans and rotifers as indicators of water quality. Trans.Am. Micros. Soc., 971:16-36.

Hynes, H. B. N. (1970). The ecology of running water. Liverpool Univ.Press., 555 pp.

Jeje,C. Y. (1988). A revision of the Nigerian species of the genera Mesocyclops Sars, 1914 and Thermocyclops Kiefer, 1927 (Copepoda: Cyclopoida). Hydrobiol., 164: 171-184.

Laal, A.k and M. Karthikeyan. (1993). Rotifers pollution or productivity indicators. Curr.Sci., 65 (11): 874-875.

Lance, G. N. and Williams, W. T. (1967). A general theory of classificatory sorting strategies. II. Clustering systems. Computer J., 10: 271-277.

Menzel, D. W. and Case, J. (1977). Concept and design: Controlled ecosystem pollution experiment. Bull. Mar. Sci., 27(1): 1-7.

Pennak, R. W. (1978). "Freshwater Invertebrates of the

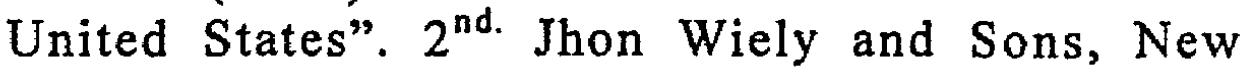
Tork, $803 \mathrm{pp}$.

Pontin, , (1978). A key to British Freshwater Planktonic Rotifera, Freshwater Biol. Assoc. Sci. Publ. 38 . Britain, $178 \mathrm{pp}$.

Ramadan, SH. E, El-Serehy, H. A. Farghaly M. E and ElBassat, R.A. (1998). Zooplankton communities in the Nile River, Egypt. Bull. Nat. Inst. Oceanogr. Fish. ARE, 24: 139-159.

Rey, I. and Saint-Jean, L. (1968). Les cladocers (Crustaces: Branchiopods) Du Tchad, Cah. O.R. S. T. O. M. Ser.II $(3-4): 22-42$. 
Reynolds, C. S., Descy, J. P. and Badisak, J. (1994). Are dynamics in rivers so different from those in shallow lakes?. Hydrobiol. 289: 1-7.

Rohlf, F.J. and Sokal, R.R. (1969). Statistical Tables. W.H.Freeman, San Francisco, 253pp.

Ruttner-Kolisko, A. (1974).Planktonic Rotifers.In"Biology and taxonomy".Binnergewasser. Suppl.,26: 146pp.

Saksena, D. N. (1987). Rotifers as indicators of water quality. Acta Hydrobiol., 15 (5): 481-485.

Sladecek, V. (1983). Rotifers as indicators of water quality. Hydrobiol. 100: 169-201.

Sobhy, E. H. M. (1999). Effect of industrial waste of Iron and Steel Factories on Nile phytoplankton communities and productivities at Helwan, M. Sc. Thesis. Fac. Sc. Menofyia Univ., 200pp.

Telesh, I. V. (1996). Species composition of planktonic Rotifera, Cladocera, and Copepoda in the littoral zone of Lake Ladoga.Hydropiol. 322:181-185. 
El Nubaria Canal

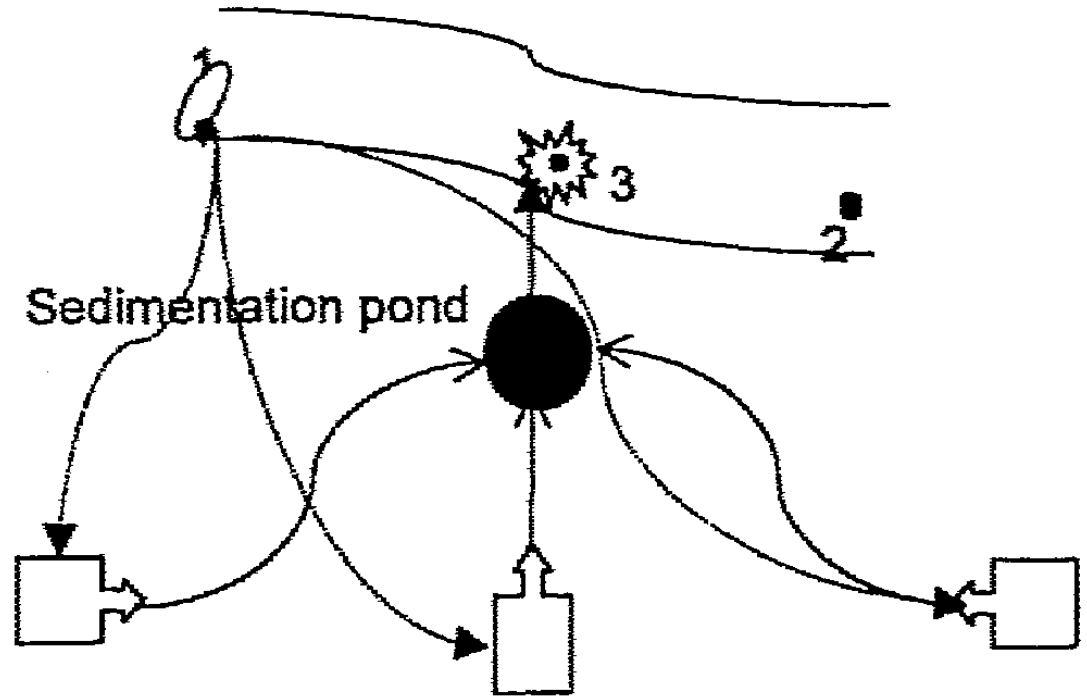

Polymer F. Vinyle F. Chloride F.

Egyptian Petrochemicals Company-Alexandria

Fig. (1): Sketch showing stations of study at El Nubbaria Canal

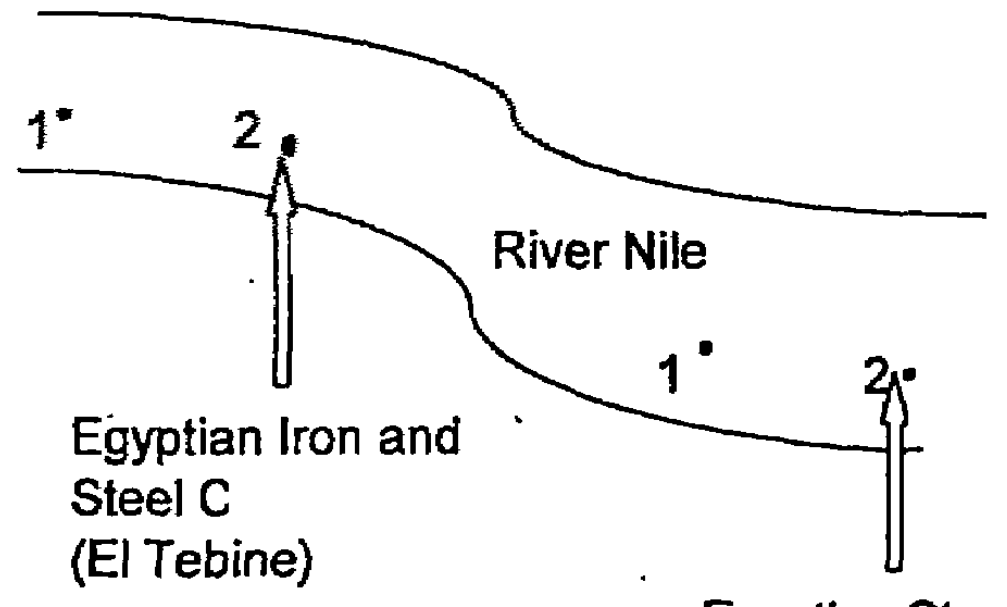

Egyptian Starch and Glucose C.

(Helwan)

Fig.(2): Sketch showing stations of study in River Nile at Helwan and El Tebin 

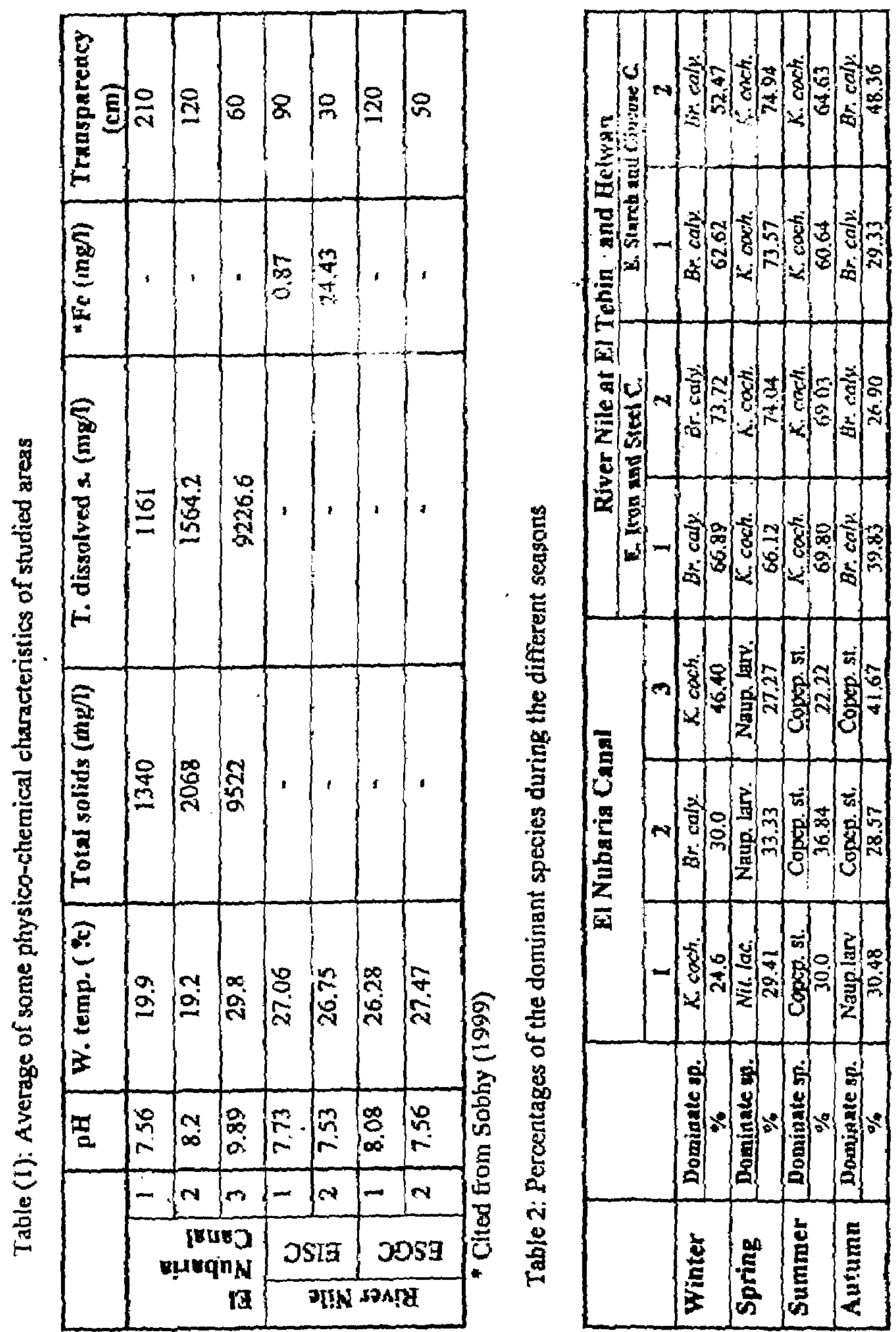


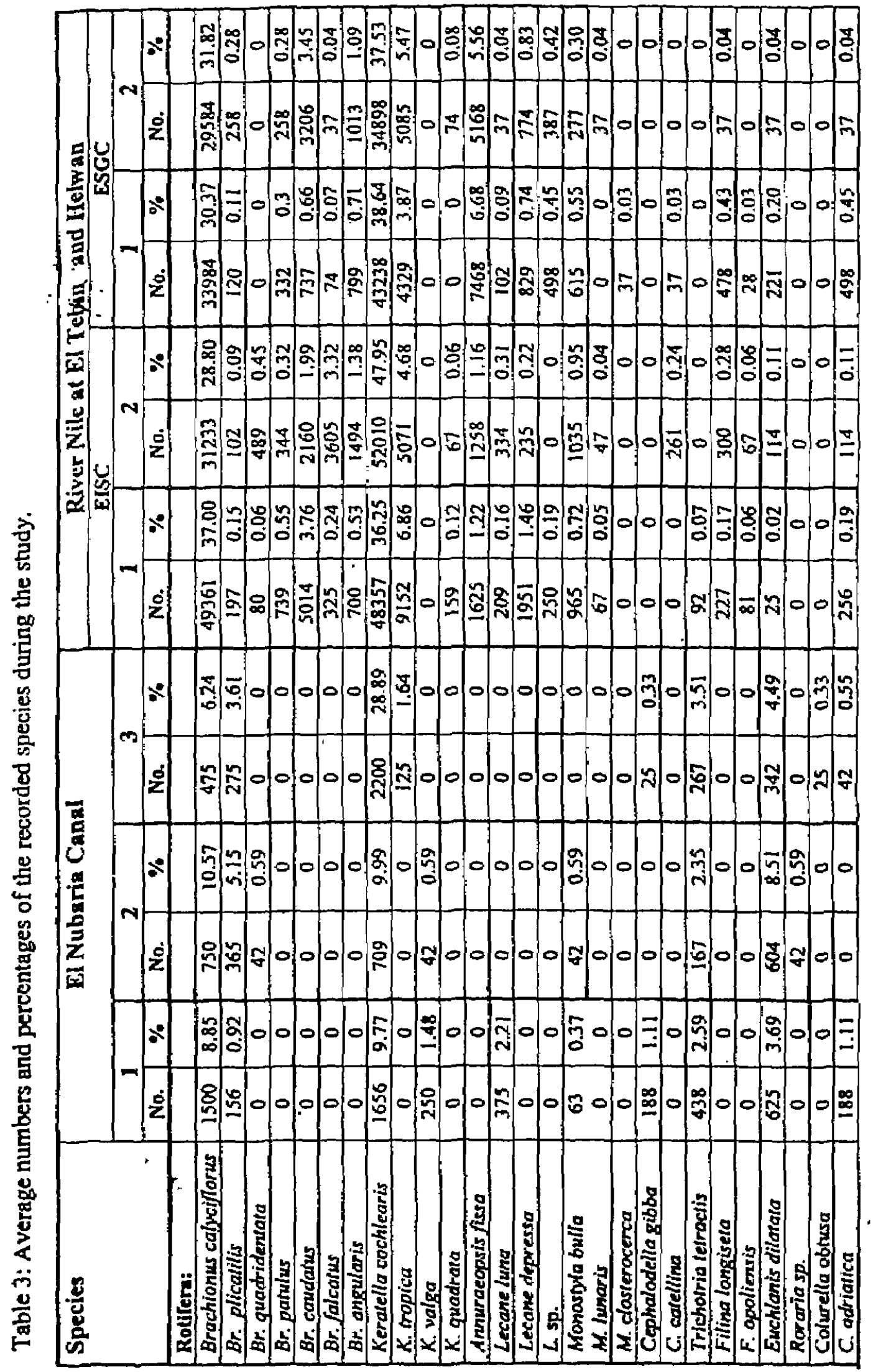




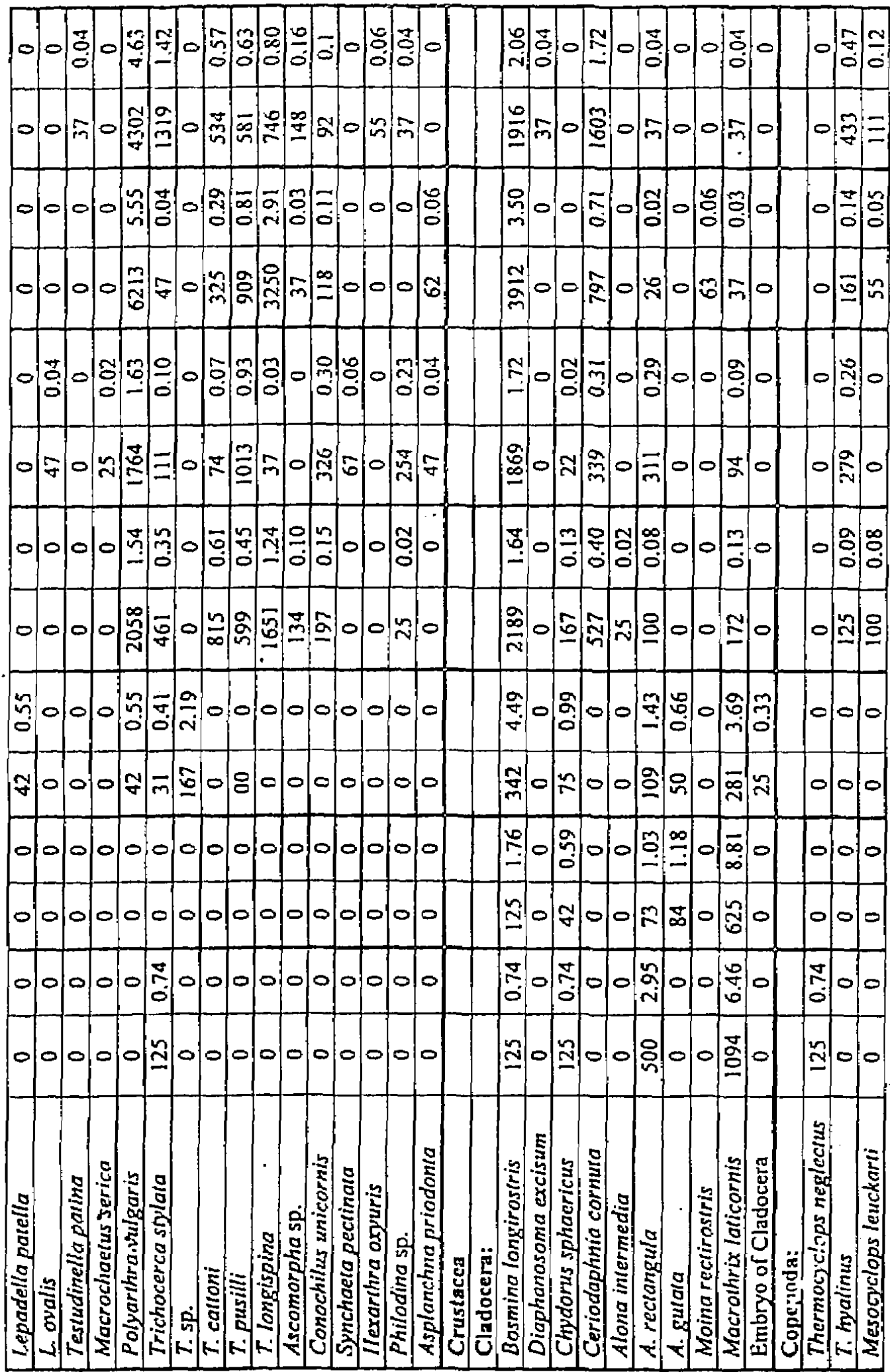



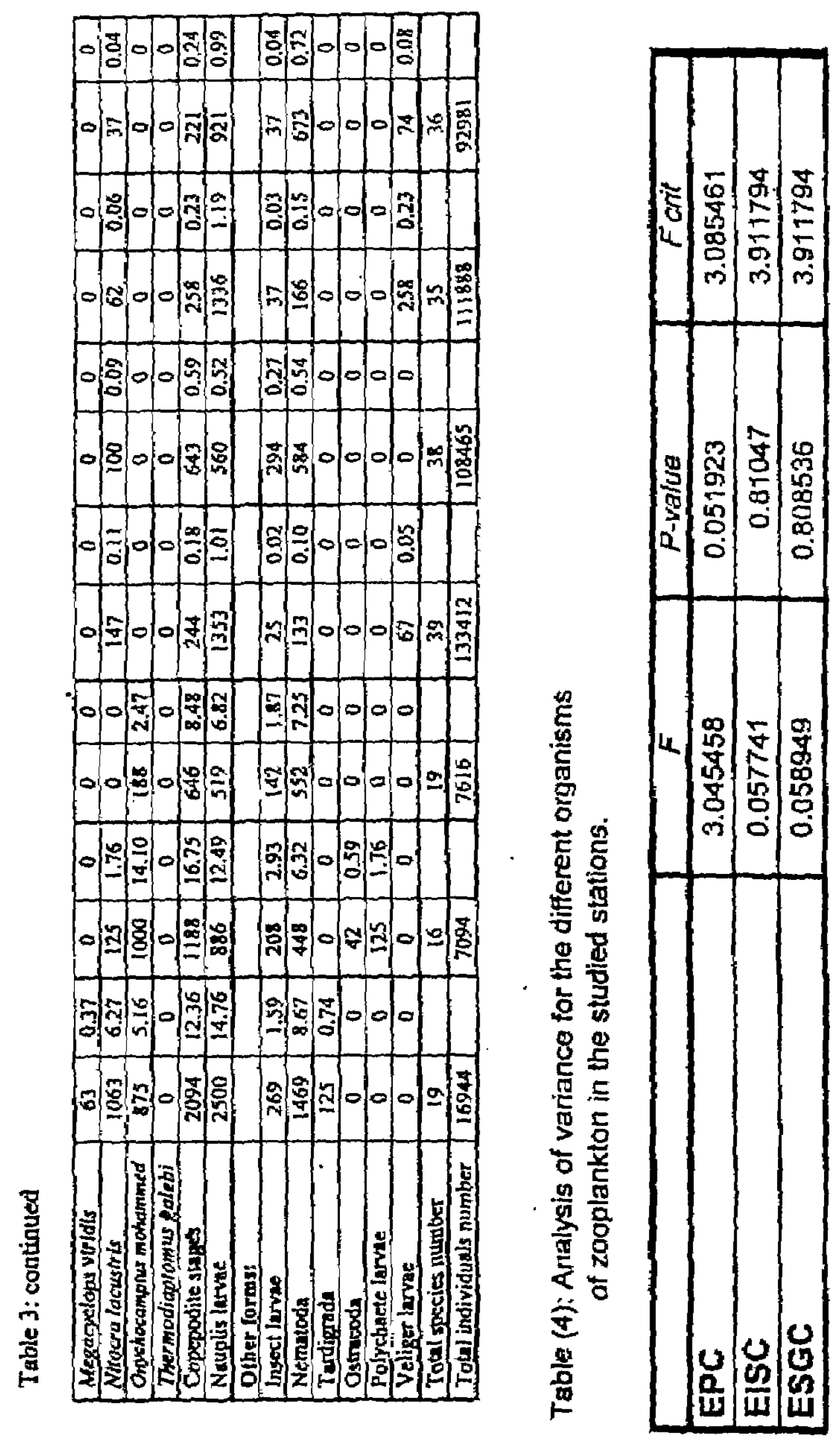


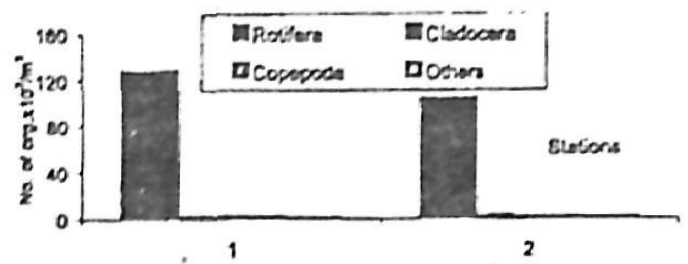

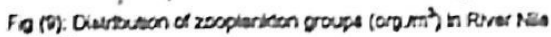
AEISC
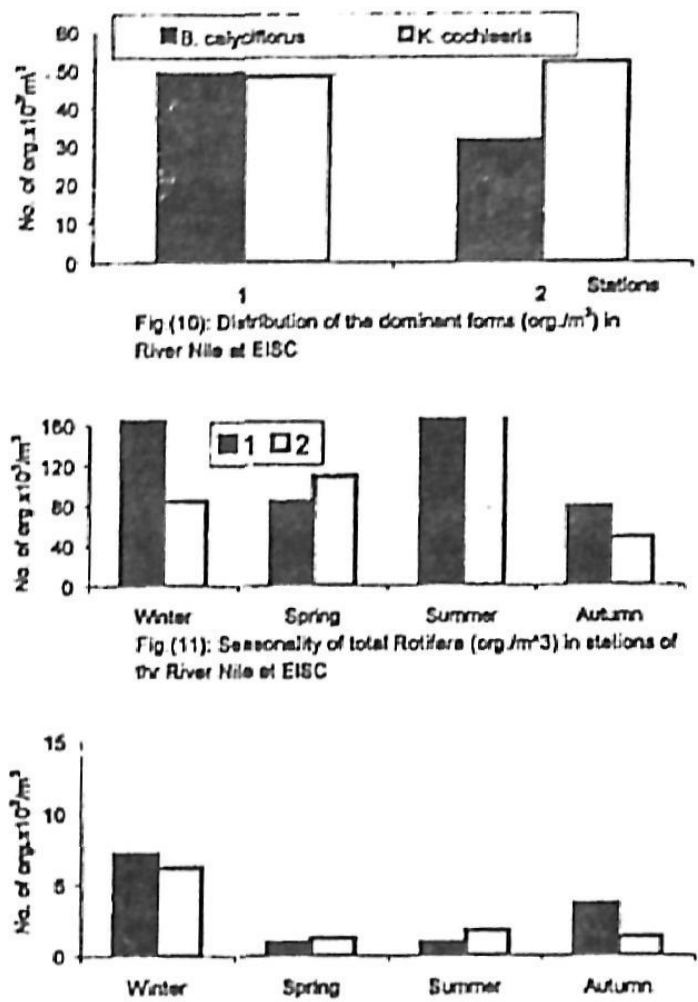

Fig (12) Seesonality of Idel Cladocere (ord $/ \mathrm{m}^{2}$ ) in stentions of tha River Nis at EISC

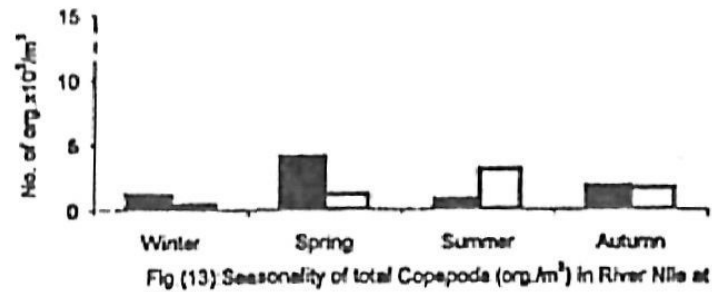
EISC

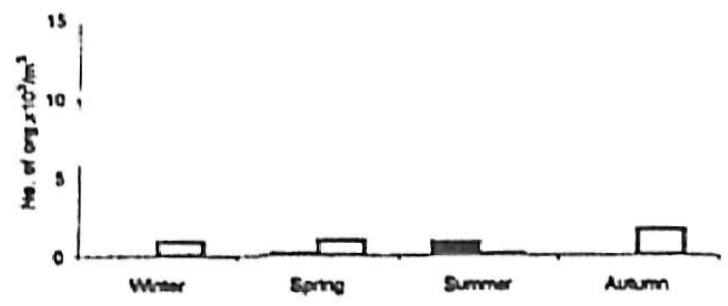

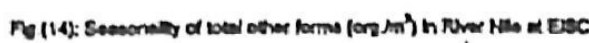

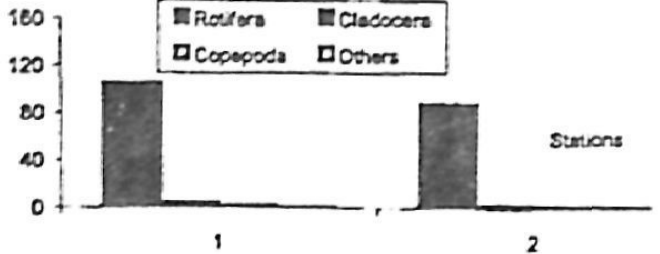

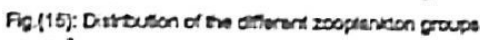

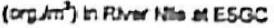

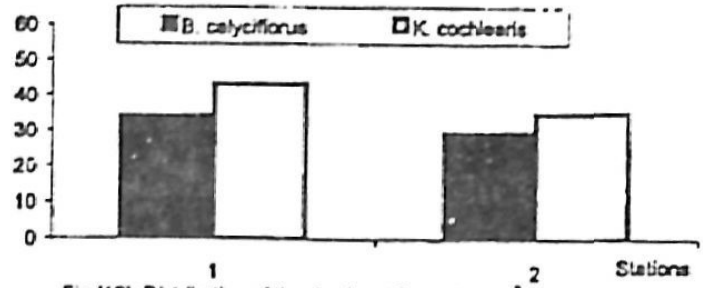

Fig.(16): Distribution of tua dominend forme (org $\mathrm{mm}^{2}$ in River Nito of ESGC

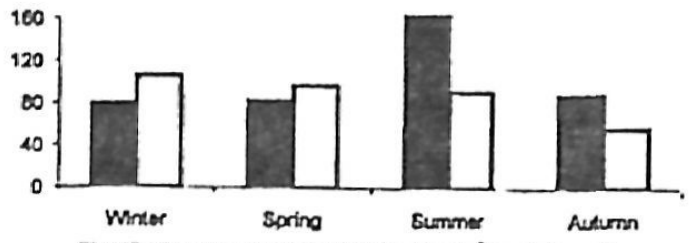

Fio (17): Seesonality of total Rorifora $\left(0 \mathrm{dg} / \mathrm{m}^{2}\right)$ in stestons of

tha River Nile et ESGC

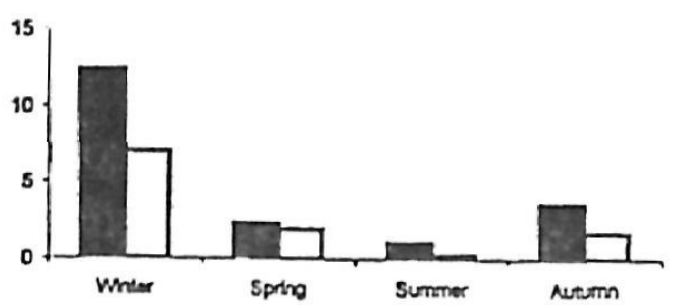

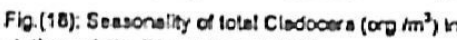
vtations of the River Nito at EEGC

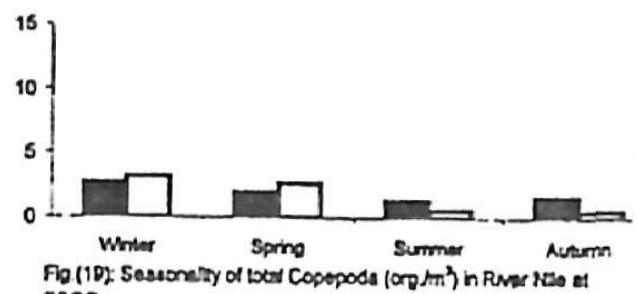
ESOC

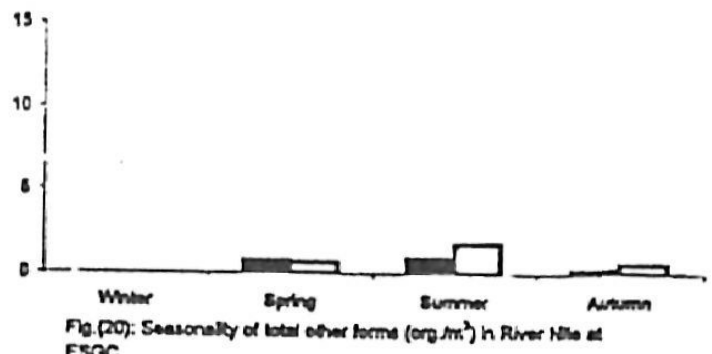




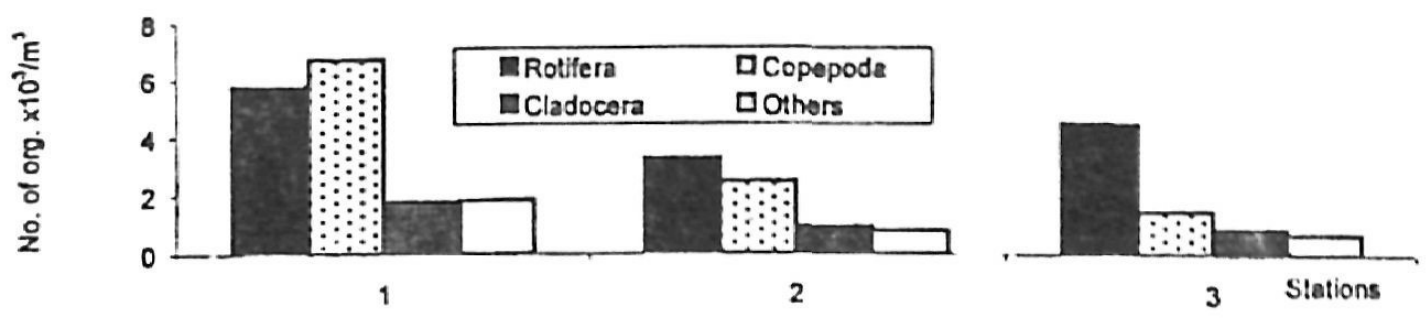

Fig.(3): Distribution of the different zooplankton groups (org. $/ \mathrm{m}^{3}$ ) at EI Nubaria Canal

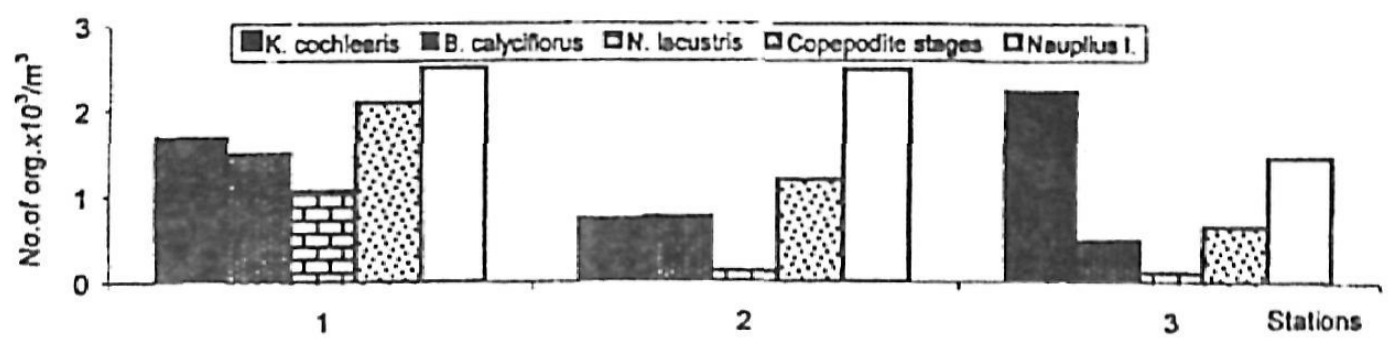

Fig.(4): Distribution of the dominant forms (org. $/ \mathrm{m}^{3}$ ) at El Nubaria Canal

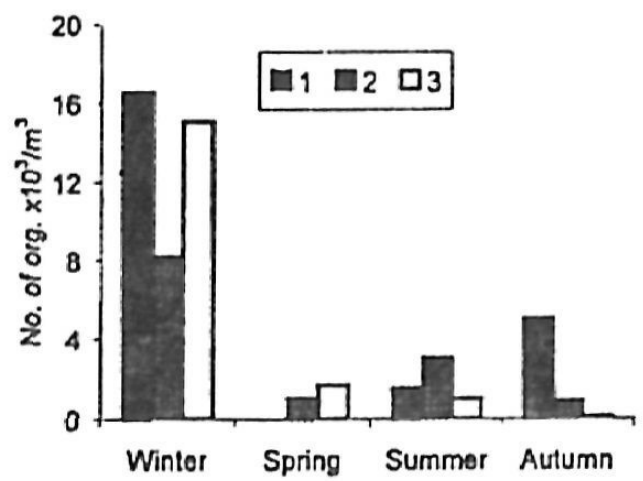

Fig.(5): Seasonality of total Rotifera (org. $/ \mathrm{m}^{3}$ ) at stations of El Nubaria Canal

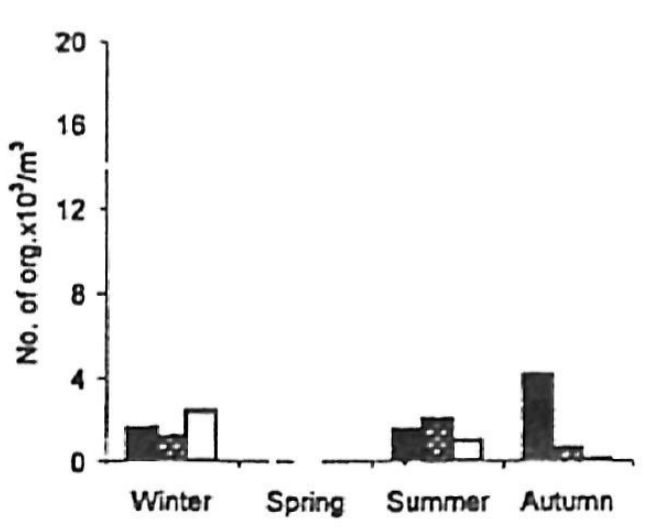

Fig.(7): Seasonality of total Cladocera (org. $/ \mathrm{m}^{3}$ ) at stations of El Nubaria Canal

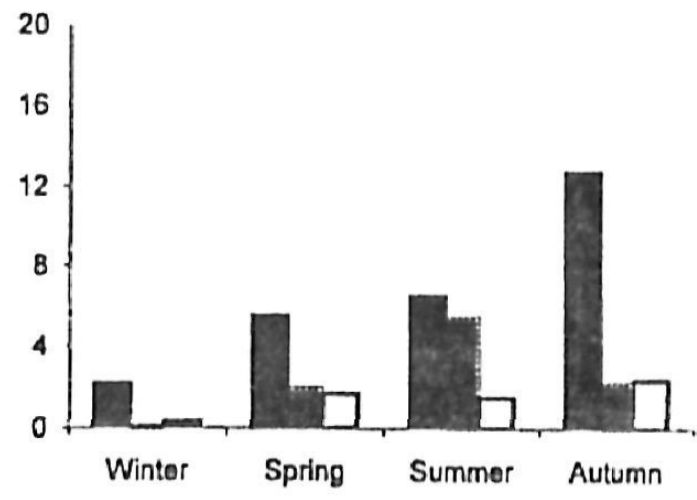

Fig.(6): Seasonality of total Copepode (org. $/ \mathrm{m}^{3}$ ) at stations of El Nubaria Cenal

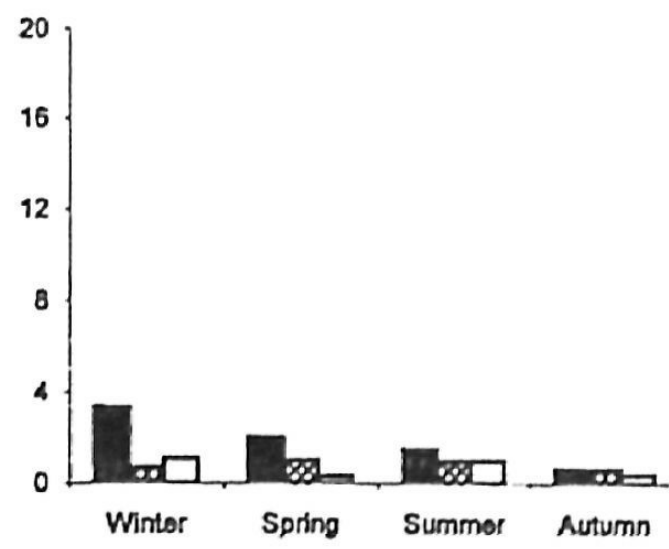

Fig.(8): Seasonality of total other forms (org. .$\left./ \mathrm{m}^{3}\right)$ al stations of El Nubaria Canal 